\title{
Genealogy: A Comparative Perspective from the Early Medieval West
}

\author{
Walter Pohl
}

Genealogies and similar forms of structuring descent were widely diffused in recorded history; indeed, they offered one basic "perceptual grid" for shaping the past, legitimizing the present and preparing for the future. ${ }^{2}$ Yet they did not carry the same weight, or have the same meaning in different historical contexts. The present article addresses the question how much they mattered in early medieval continental Europe, where and when. It will briefly reassess the evidence from the mid-6th to the mid-gth century. Taken together, the following examples provide impressive traces of genealogical thinking; they could be (and often have been) taken as tips of an iceberg, and interpreted as written traces of detailed genealogical knowledge and its oral transmission among the "Germanic" elites of the post-Roman kingdoms. I will argue that we need to be more precise and also acknowledge the limits of genealogical thinking and of its social impact: perhaps there was no single iceberg? Among the elites, noble descent may have mattered, but it rarely needed to be specified, and it seems that actual genealogical knowledge seldom stretched back more than three or four generations. ${ }^{3}$ Royal succession was usually represented by king lists rather than royal pedigrees. Strikingly, neither of these have been transmitted from the Merovingians' more than $25^{\circ}$ years of rule. Genealogies gradually become more prominent in our evidence from the Carolingian period; but it seems that the emerging Merovingian and Carolingian pedigrees were not based on pre-conceived oral genealogical knowledge ultimately written down, but were experimentally created and expanded on the basis of written documents in ecclesiastic institutions.

Comparison between genealogical thinking in the post-classical West and in Early Islamic Arabia make it possible to step back from old certainties, and assessing remarkable differences beneath certain evident similarities.

1 I would like to thank Stuart Airlie, Max Diesenberger, Nicola Edelmann, Patrick Geary, Andre Gingrich, Bernard Jussen, Daniel Mahoney, Helmut Reimitz, Pavlína Rychterová, Karl Ubl, Herwig Wolfram and Ian Wood for help and suggestions, and the entire viscom team for the creative atmosphere in the project in which my ideas could grow.

2 Spiegel, "Genealogy", 103.

3 A point already made by Wenskus, Stammesbildung, 55 .

(C) WALTER POHL, 2016 | DOI 10.1163/9789004315693_012

This is an open access chapter distributed under the terms of the Creative Commons Attribution-

Noncommercial-NoDerivatives 3.o Unported (CC-BY-NC-ND 3.0) License. 
In the early medieval West, genealogies have been transmitted in writing almost exclusively for ruling dynasties, whereas Arabic genealogies—although written from the perspectives of various elites-reference and address much broader social ranges, and are much more numerous. Tribal genealogies constructed relative distances between kin groups and tribes. Sometimes, pedigrees also make it possible to connect families or lineages with a common ancestor of a tribe, more elaborately so in Northern Arabia than elsewhere.

There is little trace of such connections between family pedigrees and tribal genealogies in the early medieval West. Conceptually, the gentes (peoples) of Latin Europe were derived from "the generations of families", as Isidore of Seville states; ${ }^{4}$ however, there is little evidence that families were ever actually traced back to common ancestors of tribes of peoples. On the other hand, the political role of ethnicity grew considerably in the post-Roman West. The polities that replaced the Roman Empire - the kingdoms of the Goths, Franks, Lombards, Anglo-Saxons and others-were generally known by the ethnic background of their ruling elites, and increasingly styled themselves as ethnic communities. ${ }^{5}$ In early Islamic polities, tribal or ethnic affiliations were relevant for access to power and privilege, but they were not the decisive criterion for the right to rule a specific realm as in Latin Europe. ${ }^{6}$ The relationship between ethnicity, kinship and political power therefore developed differently in Arabia and in the West in the Early Middle Ages. Thus genealogies represent an attractive field for comparative study of the different balances among genealogical thinking, kinship patterns, ethnic distinctions and political cohesion in the societies under scrutiny.

Daniel Mahoney's contribution in this section outlines very well that intricate and ever-shifting genealogies were an important expedient of structuring and conceiving the social world from the perspectives of tribal elites in early medieval highland Yemen. ${ }^{7}$ In the Islamic world at large, genealogies came to be written down soon after the Islamic conquest, when new tribal allegiances and social identities emerged and became relevant for the status of conquering groups. ${ }^{8}$ They seem to have been more relevant for negotiating

4 Isidore, Etymologies 9.2.1, ed. Lindsay: Gens autem appellata propter generationes familiarum, id est a gignendo, sicut natio a nascendo.

5 Pohl, "Introduction: Ethnicity, Religion and Empire".

6 For instance, Charlemagne's conquest of the Lombard kingdom in Italy in 774 was perceived as the transfer of the rule over Italy from Lombards to Franks: Pohl, "Gens ipsa peribit".

7 See the overview in Kellner, Ursprung und Kontinuität; Gingrich, "Kinship".

8 Kennedy, "Arab genealogical literature"; see also Savant and de Felipe, eds., Genealogy and Knowledge. 
status than in a comparable situation in post-Roman Western Europe. Genealogical literature acquired considerable significance in the late Umayyad and the early Abbasid periods. Genealogies mattered most for those who could claim descent from the Prophet Muhammad's lineage, the Nasab Quraysh. As early as the period up to the middle of the 8th century, "the Arabic historical sources record the names of approximately 3,000 Qurashīs of this period for whom we know the names of their fathers and at least the status of their mothers". ${ }^{9}$ After the battle of Kerbala (680) the Shi'ite claim to priority succession for members of the Prophet's house suffered a major political setback, yet this did not necessarily decrease its social relevance. In the middle of the ninth century, al-Zubayri synthesized the genealogical information about the Nasab Quraysh.

Other family pedigrees could also be attached to tribal ones, whereas tribes could be linked with each other in webs of increasing and decreasing solidarity, and traced back to Adnan and Qahtan as ancestors of North and South Arabians' regional-ethnic and tribal groupings. ${ }^{10}$ In the context of this wide framework of locating groups and individuals in a modulated network of genealogies, scholars such as the tenth-century Yemeni author al-Hamdānī produced encyclopaedic genealogical compendia and developed critical approaches to their material. Of course, and as usual with elaborate genealogies, the material could be handled very flexibly or even invented according to contemporary interests and perceptions. Some Islamic scholars were aware of that, for instance, Ibn Khaldun in the 14th century: "Pedigrees are useful only in as far as they imply close contact that is a consequence of blood ties and that eventually leads to mutual help and affection. Anything beyond that is superfluous. For a pedigree is something imaginary and devoid of reality. Its usefulness consists only in the resulting connection and close contact".11 Genealogical writing tended to decrease in importance in certain regions in later medieval Islam; Zoltán Szombathy has argued that this was due to changing academic traditions rather than to a transformation of the main social context. ${ }^{12}$ However, genealogical reasoning has remained important in some areas, such as the highlands of Yemen, up to the present day.

\footnotetext{
9 Robinson, "Prosopographical Approaches to the Nasab Tradition", 12; I am grateful to Daniel Mahoney for this and other information. See also Bernheimer, The 'Alids.

10 See the contribution by Hovden and Heiß, in this volume.

11 Ibn Khaldun, Muqadimmah 2.8, trans. Rosenthal, p. 99.

12 Szombathy, The Roots of Arabic Genealogy.
} 


\section{Genealogies in the Post-Roman Kingdoms on the European Continent (6th-8th Centuries)}

Confronted with such a high level of genealogical discourse and its written transmission, early medieval Europe (or at least its continental part) is surprisingly poor in attested genealogies. Claims of noble descent were not infrequent, but they are rarely based on elaborate pedigrees; Karl Schmid remarked that early medieval noblemen knew they had illustrious ancestors, but rarely remembered all their names. ${ }^{13}$ Most written examples, at least up to the 9 th century, are king lists of more or less explicitly dynastic character; very few aristocratic genealogies have been passed on. ${ }^{14}$ This is all the more surprising as both classical Rome and the Bible provided ample models for genealogical thinking. In the aristocracy of Republican Rome, genealogies linking families with the mythical kings of Alba Longa were frequent; these had in turn been constructed to bridge the gap between the Trojan hero Aeneas and the founder of the city, Romulus. ${ }^{15}$ Descent from the gens and the dynasty also played a role in imperial representation. ${ }^{16}$ An inscription by Septimius Severus in the theatre at Ostia gives his (adoptive) genealogy back to the Emperor Nerva, in the sixth generation. ${ }^{17}$ Such public displays of genealogical legitimacy are hard to find in the Early Middle Ages.

In the Old Testament, the patrilinear list of patriarchs from Adam to Abraham is linked by genuit, begat, and complemented by chronological information about their extraordinary life-spans, and the age at which their eldest sons were born. This was very relevant for the reckoning of time by years of the world in Late Antiquity and the Early Middle Ages. The founding fathers of Christian historiography, Eusebius and Jerome in the 4th century, left out this first part of history and started with Abraham and the first kingdom, as they believed, that of the Assyrians. Later authors, such as Jordanes in the mid-6th century, supplemented the patriarchs; he repeatedly emphasizes that in those years when humans were raw and simple, their genera, descent groups, were not ruled by kings but by the heads of families, and therefore the chronology had to be counted by families. ${ }^{18}$ The powerful Old-Testament narratives of the

\footnotetext{
13 Schmid, "Zur Problematik", 57.

14 Génicot, Les généalogies; Kellner, Ursprung.

15 Farney, Ethnic Identity, pp. 53-65.

16 Hekster, Emperors and Ancestors, esp. pp. 21-25.

17 See http://www.ostia-antica.org/regio2/7/7-2.htm (10/10/2015).

18 Jordanes, Romana 6-11, ed. Mommsen, pp. 3-4.
} 
Flood and the Tower of Babel provided two different explanations for the origins of peoples and of languages, which made Isidore of Seville in the 7 th century wonder whether peoples had sprung from languages or vice versa. The myth of the sons of Noah allowed grouping all the peoples of the known world into descendants of Sem, Cham and Japhet, and that is also how Isidore's long list of peoples is structured; only occasionally does he give more precise indications of their genealogical connections. ${ }^{19}$

In line with Old Testament prophecies, the Gospels of Matthew and Luke offered two differing genealogies of Jesus going back to David and beyond. ${ }^{20}$ Matthew even begins with the heading: Liber generationis Iesu Christifilii David filii Abraham. They also differ formally: while Matthew's pedigree descends from Abraham (following the $A$ genuit $B$ scheme), Luke's ascends to Adam and God ( $A$, qui fuit $B$ ). The different descent lines in Matthew and Luke provoked discussion, and Eusebius devoted a whole chapter of his Ecclesiastical History to a complicated argument trying to reconcile them, and maintaining that thus Jesus came both from the tribe of Judah, repository of royalty, and from the priestly tribe of Levi. ${ }^{21}$ The fact that these lines ran through Joseph, who was only the legal father, also presented a problem; in the Byzantine East, alternative genealogies through Mary were constructed. ${ }^{22}$ In the wake of Augustine, the early medieval West was not always as concerned with these genealogical problems, but they did matter, for instance in the Carolingian period. ${ }^{23}$ From the 11th-century, depictions of the "tree of Jesse" (David's father) became current in Latin Europe. ${ }^{24}$ Biblical models were widely used to structure historical time and to relate actors in the biblical narrative to one another, and their formal design remained influential wherever genealogies mattered. However, they did not inspire a profuse production of pedigrees of families and tribes in early medieval Europe.

The most impressive genealogy of the period between the 6th and the 8th century is that of the Ostrogothic Amals, who ruled over Italy in the early 6th century AD. Their Roman administrator, the senator Cassiodorus, extolled King Athalaric for being "of royal stock to the seventeenth generation", and his

19 Isidore, Etymologiae, 9.1, ed. Lindsay; Borst, Turmbau von Babel, 1:6-11.

$20 \quad$ Mt. 1:1-17; Lk. 3:23-28; Is. 11:1; 11:10; 53:3.

21 Eusebius, Historia Ecclesiastica 1.7, ed. Lake, 1:pp. 54-64; Dagron, Emperor and Priest, 313-18.

22 Dagron, Emperor and Priest, 316.

23 Leyser, "From Maternal Kin to Jesus as Mother".

24 Kellner, Ursprung, 46-49; see also Weaver and Caviness, The Ancestors of Christ Windows, and the contribution by Christian Opitz, in this section. 
mother, Theoderic the Great's daughter Amalasuintha, for having "as many kings as ancestors". This ancient lineage was highlighted to please the Roman senators, as Cassiodorus expressly stated: "As you have ever been thought noble because of your ancestors, so you shall be ruled by an ancient line of kings". ${ }^{25}$ As Herwig Wolfram has observed, the Amal family "manifests itself like a second gens Iulia". ${ }^{26}$ The Gothic history written by Cassiodorus, to which these passages refer, is lost, but was excerpted by Jordanes, who wrote a Gothic history some 20 years later, after $55^{\circ}$. Indeed, his Getica contains a genealogy of the Amals that makes Athalaric the 17 th in number. ${ }^{27}$ It is built into a literary construction which identifies the Goths with Scythians, Getae and Dacians from antiquity, and the genealogy is inserted after the account of the victory of the Dacian king Diurpaneus over the Roman general Fuscus in AD 86. This triumph gives the opportunity to claim that the success of the Goths was due to their fortune derived from their ancestors, "whom they did not call pure men, but demigods, that is, Ansis". ${ }^{28}$

Jordanes marks out the Amal genealogy with an almost tedious introduction: "I will briefly go through their genealogy, that is, who was begotten by which relative, where the origin lay and to which end it came". The eponymous founder of the dynasty, Amal, comes fourth in the list. This means that the line of descent is continued back beyond the family genealogy to include a wider stock of shared ancestors that remains hard to decode. The first of these "heroes, as they refer themselves in their fables", was Gapt. He is usually identified with Gaut, a name with strong Scandinavian associations-Gautr was one of the eponyms of the god Odin, and Gauti one of his sons. ${ }^{29}$ Gapt thus seems to have referred to a mythological patrimony related to Scandinavia, and shared by many Anglo-Saxon dynasties in whose pedigrees, as we shall see, the Old English name form Geat appears. It is implausible that Jordanes' insistent references to orally-transmitted fables are a mere authorial fabrication, and that the Goths lived on Roman soil completely oblivious of their pre-Roman past. However, such "traditions" did not feed directly and coherently into Jordanes' account, but come in disconnected fragments and are attached to an

25 Cassiodorus, Variae 11.1.9, trans. Barnish, p. 147; 9.24, trans. Barnish, p. 128; Wolfram, History of the Goths, 31 .

26 Wolfram, Gotische Studien, 154.

27 Jordanes, Getica, 14.79, ed. Mommsen, p. 76; Wolfram, History, 31. The lively debate on the "authenticity" of this genealogy (e.g. Heather, Goths in the Fourth Century; Goffart, Narrators) does not concern us here, but it was hardly made up by Cassiodor or Jordanes in its entirety.

28 Jordanes, Getica, 13.78, ed. Mommsen, p. 76; Wolfram, Gotische Studien, 29.

29 Simek, Lexikon. See also Wolfram, Goten, 31 and 37; Wolfram, Gotische Studien, 104. 
overarching construction of Gothic history devised on the basis of Roman ethnographic literature.

Remarkably, a name that we could regard as an eponymous tribal ancestor, Ostrogotha, is found two generations after Amal. In fact, a Gothic leader named Ostrogotha is not only attested to in Jordanes in a 3rd-century context (as predecessor of King Cniva), ${ }^{30}$ he (or another Gothic leader of the same name) is also mentioned as Cniva's less successful rival in newly-found fragments of the 3 rd-century historian Dexippos. ${ }^{31}$ It is thus likely that Ostrogotha in the genealogy represents an actual Gothic leader, perhaps retrospectively regarded as a mythical heros eponymos. ${ }^{32}$ Cassiodorus (or Jordanes) could have tracked down his name in third-century historiography; but then one might ask why he had been included instead of the better-known and more successful Cniva. However that may be, the clear impression is that the Amal pedigree in Jordanes is not a streamlined list carefully tailored as a whole in the 6th century. ${ }^{33}$ Traces of inner tensions and contradictions are evident. It glorified a dynasty that had fallen and become extinct in the male line; the names were Germanic, the interest in compiling the list was Roman; there is no trace of the Dacian king to whose victory Jordanes had attached it; and the links with a however imaginary shared Gothic (or Scandinavian/Germanic) past were ambiguous. The list had been patched together in 6th-century political contexts, and fused elements of a king-list with those of a genealogy to the higher glory of the Amals and of those who might have aspired to take their position. However, it must have relied on some native knowledge, for it is clearly not simply compiled from the Roman historiography available to Cassiodorus. Most remarkably, Cassiodorus's grand ethnographic construction of identifying the Goths with several previous south-eastern European peoples had no bearing on his Amal genealogy, which contained no Scythian, Getic or Dacian names. Different layers of material had been brought in line, but not smoothly merged.

On the whole, the profile of extant genealogical legitimation from other post-Roman kingdoms is relatively low. The Burgundian code lists Gundobad's "ancestors of royal memory" (all with names alliterating in G-), but the purpose

30 Jordanes, Getica 17.98-100, ed. Mommsen, p. 83.

31 Grusková and Martin, "Ein neues Textstück"; Martin and Grusková, "Scythica Vindobonensia".

32 The Dexippos passage invalidates the argument in Heather, Goths and Romans, 22, that Ostrogotha was just a mythical name-giver and not a real king.

Wolfram, Gotische Studien, 114; 218. 
is purely legal and concerns the status of freedmen and slaves. ${ }^{34}$ The Visigothic evidence is thin, apart from Jordanes' reference to the dynasty of the Balthi. ${ }^{35}$ In both the Visigothic and the Lombard kingdoms, sons (if available) ascended the throne after their fathers, but more often than not this default filial succession was soon subverted by regicide or revolt. Thus no stable dynasty established itself in the Lombard realm in Italy $\left(5^{68-774)}\right)$. Rather atypically, the 7th-century Origo gentis Langobardorum and texts based on it name the different families (genera) of these kings; often, they also mention their wives and offspring. ${ }^{36}$ The king list prefixed to the edict of King Rothari (636-653) notes filiation where it applied, and the name of the genus when a new dynasty took over. This prologue to the law code also contains the only genealogy of a Lombard king. It lists 11 male ancestors of Rothari, the genus Harodos. ${ }^{37}$ The name of the family, Harodi, corresponds to an ethnonym attested to several centuries earlier (and mentioned by Julius Caesar, among others). It is a strange list, without any of the name elements occurring in the king's own name, partly containing short appellatives (Noctzo, Mammo) together with the more prestigious "bithematic" Germanic names (such as Alamund or Rothari himself), and showing rather archaic name forms for the earlier generations. It is structured by stave rhyme pairs (Faccho-Frocho), and probably takes us as closely to orally transmitted genealogies as Latin written transmission and political expedience in post-Roman kingdoms allowed. It is in fact not a royal genealogy but that of a high aristocrat who had become king seven years earlier.

Knowledge of one's ancestors was required by Rothari's edict of 643: "He who desires the succession must be able to give the names of all his related ancestors. If litigation should be brought before a royal court, he who seeks the inheritance may offer oath with his legitimate oath-helpers to the effect: the deceased is our legitimate kinsman and we are related to him in the following manner". ${ }^{38}$ In practice, the genealogical knowledge required here would hardly go beyond one's grandfather and his offspring. A further example from Lombard Italy is the family of Paul the Deacon, who wrote a history of the Lombards towards the end of the 8th century. He interrupts his history at a point where he deals with his native city of Cividale, and announces that he

\footnotetext{
34 The Burgundian Code III, trans. Fischer Drew, p. 24.

35 Pohl, "Morbus Gothorum"; Jordanes, Getica 5.42, ed. Mommsen, pp. 64 and 29.146, ed. Mommsen, p. 96 .

36 Origo gentis Langobardorum, eds. Bethmann/Waitz, pp. 2-6; Pohl, "Gender and Ethnicity”.

37 Haubrichs, "Amalgamierung und Identität", 81 and 94-99 (philological reconstruction and commentary).

$38 \quad$ The Lombard Laws, trans. Fischer Drew, Rothari 153, p. 77.
} 
would "privately...weave in" a bit about his own genealogy. In this section, he not only names his ancestors into the fifth generation, to Leupchis who came to Italy in 568 , but also tells some stories related to them, in particular about his great-grandfather, who had been enslaved in Avar Pannonia but managed to escape. ${ }^{39}$ Paul uses the word genealogia twice in a way that makes it clear that he did not understand it as pedigree, but more broadly as his family and its history.

\section{Genealogy and the Merovingians}

The most successful ruling family of the post-Roman period, the Merovingians, who ruled the Frankish kingdom/s from c. 500 to c. $75^{\circ}$, made much less of their genealogy and their name. The name Merovingi $(i)$ is mentioned only rarely in the texts. Most Merovingian kings had several sons from a number of successive or parallel and often rather informal relationships with women, most of whom were "not of remotely equal status". ${ }^{40}$ Some were foreign princesses (but rarely treated any better for that), and the Merovingians (unlike the Carolingians) did not cultivate marriage alliances with the leading families of their kingdoms. Their sons all potentially belonged to the dynasty and were fit for succession to the Frankish throne (or had to be killed to prevent it). Dynastic politics were quite similar in contemporary Byzantium, where the "horizontal family" mattered more than the vertical structures of the dynasty, as Gilbert Dagron has put it. ${ }^{41}$ Eligibility was a political decision, not a biological given. ${ }^{42}$ Genealogy, as Régine Le Jan has stated, "justified the capacity to wield power, but not the way of transmission of that power". ${ }^{43}$ Correspondingly, historiographical interest was more in the succession of kings than in their genealogy. The first major historian of the Franks, Gregory of Tours, who wrote at the end of the 6th century, demonstrates by a display of accurate source criticism that Frankish kingship had been established rather recently. ${ }^{44}$

39 Paulus Diaconus, Historia Langobardorum, 4.37, eds. Bethmann/Waitz, pp. 131-32.

40 Wood, "Deconstructing the Merovingian family", 168; Lubich, Verwandtsein, 149-64.

41 Dagron, Emperor and Priest, 29-31. Still, fancy genealogies were produced for Byzantine emperors, see Ksrmanović and Radošević, "Legendary Genealogies".

42 Wood, The Merovingian Kingdoms.

43 Le Jan, Famille et pouvoir, 40.

44 Gregory of Tours, Historiae 2.9, ed. Krusch and Levison, pp. 52-58; Reimitz, History, Frankish Identity and the Framing of European Ethnicity, 52-55. 
The Fredegar Chronicle, in the late 7 th century, accordingly starts its Merovingian king list only four generations before the founder of a supraregional Frankish monarchy, Clovis $(482-511)$. However, it was attached to a Frankish origin legend from Troy, and thus King Priam became the first named ancestor of the Merovingians. Versions of this myth in the Chronicle and its genealogical implications differ slightly, but concur in recording a number of successive splits. Priam's son Friga became the ancestor of the Phrygians/Frisians, Francio (his son?) was the eponymous founder of the Franks and Torcoth of the Turks - a genealogy that connects the origins of a surprising set of peoples. ${ }^{45}$ The complicated Frankish origin story continues with an intermediate phase of migrations, ducal rule and wars against the Romans, up to the late beginnings of Merovingian kingship. Furthermore, Fredegar intriguingly leaves open the question who the father of Merovech was, from whom the Merovingians derived their name: one day, his mother went for a swim in the sea, and was attacked by a "beast of Neptune" called Quinotaurus; soon, she became pregnant, "whether by the beast or by her husband" Chlodio. ${ }^{46}$ What sounds like a parody of classical mythology has long been taken to reflect a genealogical role of some supernatural (bullheaded?) maritime creature, but may rather go back to a folk etymology of the ancestral name Merovech as "beast from the sea", and represent an ironical critique of the Merovingians in the Fredegar Chronicle. ${ }^{47}$ The passage also implies that what counted was the female line. Only in the Liber Historiae Francorum, written in $726 / 27$, has the narrative of Frankish origins been streamlined into a continuous Merovingian succession from father to son. Francio as eponymous ancestor of the Franks has been eliminated; the Trojans under Priam and Antenor receive the name Franks from the Roman Emperor Valentinian (II). The story is here telescoped by more than a millennium, so that Priam becomes Chlodio's great-grandfather. ${ }^{48}$

Families in the Frankish kingdoms were not devoid of family memories, both in the male and the female lines. Gregory of Tours, in the late 6th century, had a wide knowledge of his descent group, a Gallo-Roman senatorial family among whom many were bishops, and claims at some point that all but five of his predecessors in the see of Tours had been, in the rather vague phrase that

45 Fredegar 3.2, ed. Krusch, p. 93; 4.2-6, ed. Krusch, pp. 124-25; Reimitz, History, Frankish Identity and the Framing of European Ethnicity, 168.

46 Fredegar 3.9, ed. Krusch, pp. 94-95.

47 Wood, "Fredegar's Fables".

48 Liber Historiae Francorum 1-5, ed. Krusch, pp. 241-45; Reimitz, History, Frankish Identity and the Framing of European Ethnicity, 272. 
he uses, "linked to our lineage (prosapia) of relatives". ${ }^{49}$ However, his family relations have to be reconstructed from widely dispersed remarks in his works. ${ }^{50}$ His concrete genealogical memories highlight successful churchmen, such as his mother's grandfather, Bishop Gregory of Langres, to whom he dedicates a chapter in his hagiographical work Life of the Fathers. ${ }^{51}$ Senatorial origin with a good number of saintly bishops in the family, and a reliable network seem to have been decisive for ecclesiastical careers at the time; what mattered therefore were extensive bilateral parental networks, not linear descent. But these senatorial descent groups seem to have faded out in the course of the 7 th century. We can reconstruct Frankish aristocratic pedigrees, for instance of the Agilolfing group, which was related to the Bavarian dukes, from scattered references, but the sources do not give any genealogies. ${ }^{52}$ Venantius Fortunatus, who wrote his panegyric poems at Gregory's time, often underlines the noble family or progeny of the addressees, both Romans and Franks, but rarely specifies it. Only in his epitaph for the Merovingian prince Chlodobert does he list his royal ancestors from his great-grandfather Clovis. ${ }^{53} \mathrm{~A}$ group of seven male and two female Merovingian names occurs in a long series of Latin names written on the reverse of the ivory plates of the Barberini Diptych. ${ }^{54}$ As Jean Vezin has shown, rather than a genealogical fragment it is a memorial list of kings and queens of the late 6th and 7 th centuries, in which some are omitted (or illegible). ${ }^{55}$

Merovingian king lists appear only in manuscripts from the Carolingian period. Like other king lists and like Origines gentium (origin legends of peoples), they are often transmitted in law manuscripts. Examples indicate that dynastic genealogies did not appear in such manuscripts as a fully developed genre, but in a more tentative way. For instance, several of the Merovingian genealogies edited by Pertz and Krusch come from two Carolingian law-books kept in St Gall. The Codex Sangallensis 731 contains the Lex Romana

49 Gregory of Tours, Historiae 5.49, ed. Krusch and Levison, p. 262: praeter quinque episcopos reliqui omnes, qui sacerdotium Turonicum susceperunt, parentum nostrae prosapiae sunt coniuncti. On Gregory's family, see Wood, Gregory of Tours, 36-46.

$5^{0}$ Wood, "The Individuality of Gregory of Tours".

51 Gregory of Tours, Life of the Fathers 7, trans. James, pp. 43-48.

$5^{2}$ Le Jan, Famille et Pouvoir, 387-95.

53 De proavo veniens Clodouecho celsa propago,/Chlodacharique nepos Chilpericique genus. Venantius Fortunatus, Poèmes 9.4, ed. Reydellet, 3:pp. 23-24; Clovis as proavus also in 10.17, p. 97 .

54 Eckhardt, "Exkurs Iv: Merowinger im Dyptichon Barberini", 262-79; Vezin, "Une nouvelle lecture".

55 Vezin, "Une nouvelle lecture", 44. 
Visigothorum, the Lex Salica and the Lex Alamannorum and was written and illustrated in 793 by Wandalgarius in Lyons. ${ }^{56}$ It contains a Frankish king list which only begins with Chlothar II and Dagobert I, placing them in a calculation of time that starts with the fifth year of emperor Heraclius (614/15) and the fourth year of the Visigothic king Sisebut. It does not mention that the listed Frankish kings were Merovingians, nor does it mark the transition from Childeric III to the first Carolingian king Pippin III, with whom the list ends. ${ }^{57}$ Genealogical models would have been available to Wandalgarius; the codex contains a Liber Generationis of Jesus Christ from Abraham through David. ${ }^{58}$

The Codex Sangallensis 732, probably written at Freising c. 818, presents an interesting mix of the Lex Alamannorum and several catechetic texts about pilgrimages to Jerusalem or about the Virgin Mary. ${ }^{59}$ Pages 142 to 154 contain the so-called Chronica de VI aetatibus mundi, an extensive calculation of the years of the Six Ages of the World. Genealogy structures the first age of the Old Testament patriarchs, for which their age at the birth of their successor is given; then the principle of calculation switches to king lists of Israel, Persia, the Hellenistic kings, and the Roman emperors up to Justinian II. From there, omitting the Merovingians, it turns to the Carolingian mayor of the palace, Pippin II, and continues until the 42nd year of the rule of Charlemagne. The idea that the years of the world are to be counted per familias of the patriarchs before kings whose reigns can be reckoned appear goes back to Julius Africanus and Eusebius, and is attested to in Jordanes' Romana; the model of the Six Ages of the World was first used in historiography by Isidore of Seville. ${ }^{60}$ In a sense the Chronica ends with a family, the Carolingians, but formally it is structured as a king list, and that conforms with the overall logic of the text: family mattered before kings took over. The Chronica de VI aetatibus spread fast as a result of a synod at Aachen in 809, which dealt with issues of the reckoning of time; the Sangallensis 732 is an early example. ${ }^{61}$ Then the rubric announces Incipit generatio regum, and starts with a brief and rather concocted list of Roman kings in Gaul with distorted names, from the primus rex Romanorum Analeus to Aegidius and Syagrius. Then the so-called "Frankish Table of Nations" is

$5^{6}$ See http://www.e-codices.unifr.ch/en/list/one/csg/o731, accessed 23/12/2014; cf. Schott, Lex Alamannorum.

57 Codex Sangallensis 731, pp. 293-94; Regum Francorum Genealogiae, ed. Pertz, pp. 307-08. See McKitterick, Charlemagne, 70.

$5^{8} \quad$ Codex Sangallensis 731, pp. 231-33.

59 See http://www.e-codices.unifr.ch/en/list/one/csg/o732, accessed 23/12/2014.

6o Jordanes, Romana 6-12, ed. Mommsen, pp. 3-4.

61 Most recently edited as Die ostfränkische Ahnentafel von 807, ed. Borst; see Corradini, "ZeitNetzWerk", 76-120. 
inserted (see below), which has Romans, Britons, Franks and Alamanni descending from a common ancestor, Escio; it should obviously demonstrate that the rule had passed to a people related to the Romans. ${ }^{62}$ The text continues with a second rubric, De regum Francorum, starting with Chlo[d]io; unlike the king list of the Sangallensis 731, the names are connected with genuit, begat, just like the Old Testament genealogy in the previous text. The list ends where the one in the Sangallensis 731 begins, with Dagobert. ${ }^{63}$

On the whole, the two St Gall manuscripts allow several observations. The character of a king list prevailed even where a genealogical element was introduced; these lists occurred together with law books; no names of dynasties were mentioned. Old-Testament-based genealogies were present in both manuscripts, which could serve as a formal model (descent lists connected by the verb genuit). Even where genealogies of peoples appear alongside the king lists (such as the genealogy of Noah or the Frankish Table of Nations), no clear link with the dynastic genealogy is established. The connection was between king lists, genealogies and the reckoning of time. Women do not play a role in the catalogues. And finally, the lists and genealogies were all incomplete, and often combined genealogically disparate elements connected by succession in rulership.

\section{The Emergence of Genealogies in the Carolingian Period (Later 8th-9th Centuries)}

The creation of a Carolingian genealogy was entrusted to an intellectual from abroad: Paul the Deacon. In his Liber de Episcopis Mettensibus, he "provides the first genealogy of the Carolingian dynasty, one that places Arnulf...at its origins". ${ }^{64}$ Paul wrote the text during his stay in Francia in the mid-780s, commissioned by Bishop Angilram of Metz, who sought to promote the interests of his church and his family at court (in 794, his cousin Irmingard would be married to Charlemagne's son Louis the Pious). According to Paul, Charlemagne's

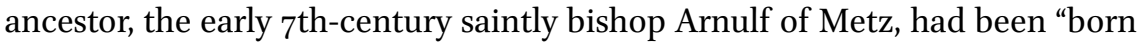
from a most noble and strong Frankish pedigree" (he does not mention the

\footnotetext{
62 Cf. Goffart, "Frankish Table", and see below.

63 Codex Sangallensis 732, pp. 154-55; Catalogi regum Francorum praetermissi, ed. Krusch, p. 851 .

64 Kempf, "Introduction", 1. For a lucid general discussion of Carolingian genealogy and the alternative between an 'Arnulfing' and 'Pippinid' lineage, see Bouchard, "The Carolingian Creation", 106-25.
} 
names). Paul takes care to explain that Arnulf's sons came from an early marriage before he had become a bishop. His younger son (otherwise known as Ansegisel), according to Paul, was called Anschises, after Anchises, the father of Aeneas, because the gens Francorum traced their origin back to the Trojans. ${ }^{65}$ As Anschises, unlike his elder brother, had given his inheritance to the poor at his father's behest, Arnulf "blessed him and all his offspring that would be born in the future", a scene that recalls the blessing of Jacob by Isaac. ${ }^{66}$ Paul thus rather subtly links the Carolingians with Frankish origins from the Trojan prosapia as a whole (without trying to construct any direct genealogical link between Arnulf and the presumptive Trojan forefathers), and sanctifies the entire Carolingian/Arnulfing progenies, without ever using their dynastic name. He does not mention that Anschises/Ansegisel married Begga, the daughter of Pippin I, mayor of the palace, and continues directly with his son Pippin II, and from there follows the male line to Charlemagne. ${ }^{67}$ Father and son are connected by genuit and each ruler receives a brief description of his achievements. Women only appear in the present, when Paul dwells at length on Charlemagne's wives and the sons and daughters they bore him. Finally, he quotes the verse epitaphs of three Carolingian princesses who were buried in Metz, which Charlemagne had asked him to write. The first of these epitaphs, for Pippin III's daughter Rothaid, again rehearses the entire line of descent from Rothaid and her brother Charlemagne back to Arnulf. ${ }^{68}$ As Paul's account shows, Charlemagne was interested in his pedigree-in the words of Janet Nelson: "The picture Paul paints of his patron is not just of a garrulous narrator of barbarian histories, nor in any simple sense of a purveyor of oral traditions. Instead, Paul's Charlemagne had reflected long and hard on the history of his lineage, allowed a place for religious preoccupations in his ancestor's secular career... a thinking man, convinced that God intervened directly in affairs of his own family, and willing to read biblical typology therein". 69

An alternative Pippinid-Carolingian genealogy would have been available, that of Pippin I. One of his daughters was the saintly Geretrud of Nivelles, whose Vita was probably composed in the later 7 th century. ${ }^{70}$ It contains a telling remark about her descent: "It would be tedious to insert in this account

\footnotetext{
65 Paulus Diaconus, Liber de Episcopis Mettensibus, ed. Pertz, p. 264.

66 Goffart, "Narrators", 374.

67 Wood, "Genealogy Defined by Women".

68 Paulus Diaconus, Liber de Episcopis Mettensibus, ed. Pertz, p. 265: genus [...] excelso de germine.

69 Nelson, "Charlemagne the Man", $3^{2-34 .}$

$70 \quad$ Heinzelmann, "L'hagiographie mérovingienne", 79.
} 
in what line of earthly origin she was descended (quo ordine de terrena origine genealogiam adsumpserat). For who living in Europe does not know the loftiness, the names and the localities of her lineage (progenies)?"71 This appears to be the earliest attestation to the word genealogia in a Frankish source, and it allows interesting observations about terminology. Yet the (male) ArnulfingCarolingian lineage prevailed over the (female) Pippinid one. For instance, Thegan placed it at the beginning of his Life of Louis the Pious; here, it was complemented by a genealogy of Louis' mother Hildegard, remarkably starting with her mother and only then tracing the male line to the Alamannic duke Gotefrid in the fifth generation. ${ }^{72}$ During a long vacancy of the see of Metz after Angilram's death in 791, Paul's Arnulfing genealogy had already been further extended in a text called in an early manuscript Commemoratio de genealogia domni Arnulfi episcopi et Confessoris Christi. ${ }^{73}$ Here, a link to the Merovingians was established. The first ancestor is Ansbert ex genere senatorum, from senatorial stock, who married Chlothar II's daughter Blithild-the connection with the Merovingian dynasty ran through the female line, whereas the male progenitor was an obscure Gallic senator with a Frankish name. ${ }^{74}$ Was that what Paul the Deacon called "a noble Frankish pedigree"? The generations between Ansbert and Arnulf are dominated by bishops, confessors and a holy virgin. The message, in line with Gregory of Tours, was clear-the Carolingians owed their success, but also their responsibility to an early progeny of saintly clerics. ${ }^{75}$ Conrad Leyser has placed this emerging interest in Carolingian genealogies in the context of Marian devotion and of intense exegetical effort to deal with the garbled pedigree of Jesus in the Gospel of Matthew. ${ }^{76}$ In spite of its unspectacular beginnings (by later standards), the Genealogia domni Arnulfi was widely circulated, and its female link between the Merovingian and Carolingian dynasties became mainstream. Not only the church of Metz sought genealogical proximity to Carolingian ancestors; later

$71 \quad$ Vita Sanctae Geretrudis A and B, Prologus, ed. Krusch, p. 454; translation and commentary (and a probable date of c. 670): Fouracre and Gerberding, Late Merovingian France, pp. 303 and 319 .

72 Thegan, Vita Hludovici, p. 176; in Walahfrid's Prologue (ibid. p. 168) the geneaology is described as series regii generis Francorum.

73 Edited as Commemoratio genealogiae domni Karoli gloriosissimi imperatoris by Georg Waitz; see Oexle, "Die Karolinger und die Stadt des heiligen Arnulf”; Reimitz, "Anleitung zur Interpretation”; Reimitz, "Die Konkurrenz der Ursprünge“.

74 Le Jan, Famille et pouvoir, 203.

75 Reimitz, "Anleitung zur Interpretation", 169-72; Leyser, "From Maternal Kin to Jesus as Mother", 29 .

76 Leyser, „From Maternal Kin to Jesus as Mother”. 
in the 9th century, the monastery of St Wandrille inserted its founder, Wandregisel, into the pedigree as Saint Arnulf's nephew. ${ }^{77}$ As Helmut Reimitz has shown, several manuscripts of Carolingian history books after the mid-gth century contain Genealogiae regum Francorum that attach the Carolingians to the Merovingians through Blithild. ${ }^{78}$ In some cases, the fierce competition between Carolingian rulers in the divided empire in the later gth century made royal genealogy a field where legitimation was sought by subtle modification. ${ }^{79}$ On the other hand, clerics could remind their rulers that kings did not acquire their position by their ancestry, but by the grace of God..$^{80}$

After the demise of the Carolingian dynasty, Carolingian origins could in some contexts become an attractive political expedient. In the later Middle Ages, more and more noble families claimed to be descended from Charlemagne. ${ }^{81}$ Pedigrees gradually became more elaborate. Merovingian genealogies were complemented on the basis of Merovingian historiography, sometimes with an imaginative turn. ${ }^{82}$ While royal continuity and Carolingian origins became important for political status in France, in Germany actual Carolingian links could also be forgotten: in the 12th-century Genealogia Welforum, Welf and his daughter Judith, wife of the emperor Louis the Pious, were not featured. ${ }^{83}$ Ottonian descent seems to have been politically more relevant. When in the 13th-century Holy Roman Empire the election of kings was formally restricted to seven prince-electors (Kurfürsten), all four lay families who achieved that privilege traced themselves back to the first Ottonian king,

77 Reimitz, “Anleitung zur Interpretation”, $176-77$.

78 Reimitz, "Ein karolingisches Geschichtsbuch". For 1oth- to 12th-century genealogies following the Ansprand-Blithild model, see Genealogiae Karolorum, ed. Waitz.

79 Basic but debatable editions: Regum Francorum Genealogiae, ed. Pertz; Catalogi regum Francorum praetermissi, ed. Krusch.

8o Nemo regum a progenitoribus regnum sibi administrari, sed a Deo veraciter et humilter credere debet dari: Concilium Parisiense a. 829, ed. Werminghoff, p. 655. See also Jonas of Orléans, De institutione regia, ed. Dubreucq.

81 See a number of high medieval genealogies edited by Georg Waitz in MGH Ss 13, pp. 241-59, 344-45 and 726-36. West, "Dynastic historical writing", 510-16, with interesting comparative observations.

82 The Genealogia Sancti Arnulfi was also complemented with previous ancestors, for instance in the 12th-century Genealogia ex stirpe sancti Arnulfi descendentium Mettensis, ed. Heller, pp. 381-82, which starts with Anafledes regina Gothorum as a mother of the four sons of Clovis, without mentioning Clovis himself. In fact, Audofleda was Clovis's sister and indeed married to the Ostrogothic king Theoderic. It is remarkable that this genealogia ... que ex regibus Francorum originem sumpsit (p. 381) begins with a woman, and a Gothic queen. Cf. Wolf, "Königswähler".

83 Genealogia Welforum, p. 733; Geary, Phantoms of Remembrance, 51. 
Henry I, through the female line (Töchterstämme). ${ }^{84}$ It is remarkable how frequently in the European Middle Ages genealogical links to ancient royal lineages were constituted by women and not through male sidelines.

The gradual and rather fragmentary emergence of genealogical writing in the 8th and 9th centuries indicates that there was no developed oral genealogical memory that could simply be put down in writing when it was needed. Early Carolingian genealogies were not only written down by clerics, they were also linked to ecclesiastical memoria. These genealogical constructs involved bishops, senators, martyrs, abbots and nuns, and were attached to a more ancient royal pedigree through the female line. No more convincing alternative seems to have been available. Of course, spiritual capital and saintly ancestors were assets in Carolingian political culture. Yet even dissent was expressed by modifying the Genealogia Arnulfi, and not by producing a more Germanic and war-like pedigree. The evidence for efforts of aristocratic families to preserve their genealogical record in the 9th to 11th centuries remains rather scarce, but makes it possible to detect a shifting balance between memory and oblivion. ${ }^{85}$ Apart from educated monks or clerics, women also cared for family memories; thus, in the mid-gth century, Dhuoda admonished her son to remember his genealogia. ${ }^{86}$

In the Carolingian period, genealogia could also be used in a broader sense. The word is not attested to much in the pre-Carolingian centuries. It is remarkable that the word does not occur in the Etymologies of Isidore of Seville, in spite of very detailed lists explaining the terminology of kinship and ethnicity. ${ }^{87}$ In the 8th century, it was increasingly used for the family itself. ${ }^{88}$ An early example is found in the Liber Historiae Francorum, written in 726/27. In a civil war between two Merovingian rulers, Chlothar II is said to have reproached his enemy, Queen Brunichild: "Why have you dared to kill so many of the royal family, tanta genealogia regale?"89 A broader social panorama emerges from 8th-century Bavarian sources. The Bavarian law book, the Lex Baiuvariorum, establishes that five named genealogiae, families or clans, enjoy special privilege and receive double compensation for any offences because they are the "the first" after the ducal dynasty of the Agilolfings. This clause also states that

\footnotetext{
84 Wolf, "Königswähler".

85 See Geary, Phantoms of Remembrance, 48-80.

86 Dhuoda, Liber Manualis, 10.5, ed. Thiébaux, pp. 226-29; Geary, Phantoms of Remembrance, 49; Thiébaux, "Introduction", 30-32.

87 Isidor, Etymologiae 9.4-6, ed. Lindsay.

88 See the list of sources in Murray, Germanic Kinship Structure, 99-108.

89 Liber Historiae Francorum 40, ed. Krusch, p. 310.
} 
the dukes always had to come from the genus of the Agilolfings, without referring specifically to their genealogy.$^{90}$ Genealogia could also denote social and legal status, as in the clause about the double compensations paid to monks, to be fixed secundum genealogiam suam, each according to their legal status (defined by their kin). ${ }^{91}$ By the Carolingian period, the term in its non-technical meaning had penetrated deeply into the social tissue, as is demonstrated by several occurrences in charters and legal formulae, where the properties of genealogiae can be transferred, mostly in cases where uncultivated land was shared by inheritance communities..$^{92}$ The term could even be used to locate land, as in a formula from Passau, which dealt with the transfer of a property in vico et genealogia, in the village and (land owned by a) genealogy. ${ }^{93}$ Vague ideas of lineage were relevant in questions of inheritance, and these genealogiae were pictured in the legal sources as a succession of property owners who had, collectively or individually, legally inherited the land, although none of the charters contains any explicit reference to predecessors or pedigrees.

\section{Genealogical Multiplicity on the British Isles (8th-1oth Centuries)}

In England, royal genealogies are already well attested in the 8th century. Bede, in the 730s, gives brief genealogies of the kings of Wessex, as descended from the leaders of the invading Saxons, Cerdic and Cynric, and of Kent, traced back to the brothers Hengist and Horsa, and beyond that, to Woden, interestingly through alliterative names. As Bede remarks, the dynasties of many kingdoms had originated from Woden's lineage. ${ }^{94}$ This probably reflects attempts in specific 8th-century constellations to project a common denominator into the

9o Lex Baiwariorum 3.1, ed. Schwind, pp. 312-13.

91 Lex Baiwariorum 1.8, ed. Schwind, p. 279.

92 For instance, n. 5, in Bitterauf, Traditionen. For this and other examples, see Murray, Germanic Kinship Structure, 99-108. Murray's agenda is to argue against the notion that these genealogiae represent traditional Germanic patrilineal clans, and indeed this evidence cannot be used to hypothesize about more ancient Germanic kinship structure. For that argument it would not be necessary to downplay, as he does, the idea of descent groups that lies in the terminology.

93 Collectio Pataviensis 5, ed. Zeumer, p. 459; Murray, Germanic Kinship Structure, 105.

94 Hengist and Horsa erant autem filii Victigisili, cuius pater Vitta, cuius pater Vecta, cuius pater Voden, de cuius stirpe multarum provinciarum regium genus originem duxit. Bede, Historia Ecclesiastica, 1.15, ed. Colgrave/Mynors, pp. 50-51, cf. ibid. 2.5, ed. Colgrave/ Mynors, pp. 150-51; cf. Dumville, "Kingship, Genealogies and Regnal Lists", 79. 
past. ${ }^{95}$ The "Anglian collection" of genealogies is supposed to have been composed in Northumbria in the 760 os/770s. ${ }^{96}$ The oldest extant, late-9th-century manuscript of the Anglo-Saxon Chronicle from Winchester (often called the A version or the Parker Chronicle), contains rich genealogical material, and starts with the genealogy of King Alfred of Wessex, again through Cerdic to Woden. ${ }^{97}$ Further back in Aethelwulf's pedigree, the Wessex genealogy is extended as far as Noah and Adam. ${ }^{98}$ The B version, written in the 970s, even introduces a further son of Noah, called Scef and born on the ark, as an ancestor of the kings of Wessex..$^{99}$

In the Chronicle, pedigrees are usually given at the beginning of a king's reign to legitimize his accession, "to provide for the current ruler the cynn (kin) which makes him cyning (king)".100 In Old English, cynedom (kingdom) is actually derived from "kin-dom", and the royal kindred could be marked out as cynecynn, "kinly kin". ${ }^{101}$ Each successive ruling family is linked back to the leaders of the invasion, and often beyond that, to the mythical ancestors, which involves a good number of ambiguities and contradictions, not least in the Wessex genealogies. The god Saxnot, also revered on the continent, featured at the beginning of the genealogy of the kings of Essex, where he was later made a son of Woden. A Scandinavian element, and a link to the Amal genealogy, appears in Geat/Gaut. Asser's Life of Alfred starts with Alfred's extensive genealogy ascending via Scyld, founder of the Danish (Scylding) dynasty, Wodan and Geat to Adam. Here, Geat is specially highlighted, and receives an interpretatio Romana, being identified with "comedy's absurd Geta" as mentioned by the late antique poet Sedulius. This strange equation shows that the author possibly valued Latin poetry higher than the household names of distant pedigrees, or was even making fun of the pagan god. ${ }^{102} \mathrm{~A}$ second and briefer genealogy of Alfred's mother follows, with a claim that her grandfather was a Goth,

\footnotetext{
95 Dumville, "The Anglian Collection".

96 Dumville, "Kingship, Genealogies and Regnal Lists", 72-104; short overview in Thornton, "Genealogies, Royal", 199-200.

97 The Anglo-Saxon Chronicles, trans. Swanton [A], pp. 2-4.

98 The Anglo-Saxon Chronicles, trans. Swanton a. 855 [A], p. 66.

99 The Anglo-Saxon Chronicles, trans. Swanton a. 855 [B], p. 67; see Anlezark, Water and Fire, 245-73, who links Sce(a)f with the Seth in Asser's genealogy of Alfred (Asser, Life of King Alfred, trans. Keynes and Lapidge, p. 67) and with the Danish king Scylf's epithet Scefing in the prologue of Beowulf, and regards him as a Wessex addition probably going back to Alfred himself.

100 Charles-Edwards, "Anglo-Saxon kinship revisited", 187.

101 Charles-Edwards, "Anglo-Saxon kinship revisited", 189-92.

102 Asser, Life of King Alfred, trans. Keynes and Lapidge, 67.
} 
"for he was descended from the Goths and Jutes". The identification of Goths and Jutes seems to be derived from an Isidorian approach to etymology based on equation between similar names, and from rather vague ideas about Scandinavia; thus, Jutland and Gotland, Geat and the Geats (Beowulf's people in the Anglo-Saxon Beowulf epic), Goths, Jutes and Danes became loosely amalgamated. ${ }^{103}$ Scandinavian origins and Danish royal ancestors were surely attractive for a king who spent much of his reign fighting Danish invaders.

The competition between the Anglo-Saxon kingdoms and their dynasties, their need to find some common ground during the process of unification, the confrontation with external forces on the British Isles (Britons, Scots or Vikings), and the interest in defining relations with the continent (not only with the "old" Saxons) and Scandinavia provide some likely motives for the literate and political interest in genealogies. The interest seems to have declined in England in the 1oth and 11th century. ${ }^{104}$ Eighth-century missionaries promoted the notion of a blood relationship with the "old Saxons" on the continent in order to win support for their efforts to convert them-it is in this context that we find one of the strongest statements of a blood relationship between members of an ethnic group, even centuries after the former unity had been broken. In c. 738, Saint Boniface, an Anglo-Saxon and a leading missionary impresario in the eastern periphery of the Frankish kingdoms, wrote to the Anglo-Saxons at home asking them to pray for their pagan brothers on the continent: "Take pity on them, for they also keep saying, 'We are of one blood and one bone". ${ }^{105}$ Boniface's argument seems to reflect a sense of common origin between insular and continental Saxons; still, his intention in promoting it is clear. Can we take this strong but rather isolated statement as an indication that common blood was regarded as defining a people, and even as constituting kinship between peoples? Boniface's argument must have latched on to existing attitudes to be plausible, but it is also remarkable that a Christian missionary was the only one to use it so emphatically.

Traditional scholarship has assumed that ideas of ethnic origins and common descent expressed in orally transmitted lineages were an archaic Germanic characteristic that had been marginalized on the continent by Latin written

103 Nelson, "Reconstructing a Royal Family", 50-52; Dumville, "The West Saxon Genealogical Regnal List"; Murray, "Beowulf, the Danish Invasions, and Royal Genealogy"; Beck, "Genealogie".

104 Dumville, "Kingship, Genealogies and Regnal Lists", 95.

105 Bonifatius, Epistolae 46 (c. 738), ed. Tangl, p. 75: Miseremini illorum, quia et ipsi solent dicere: De uno sangue et de uno osse sumus. 
culture. ${ }^{106}$ At first glance, it may seem plausible that in Britain, where vernacular literacy was already well-established since the 7 th century, Germanic-style genealogical reasoning may have surfaced more easily than on the continent. A somewhat parallel case is constituted by Scandinavia, where the sagas often focus on ideas of kinship. ${ }^{107}$ Unfortunately, their written transmission is much later than the period under scrutiny here, and one of our main witnesses is Snorri Sturlusson in the early 13th century, a Christian intellectual in Iceland with a Latin education. Much of the seeming plausibility of the Germanic argument relies on the colourful reconstruction of "authentic" Germanic culture and religion, to which generations of scholars since the Brothers Grimm have contributed. It was based on a very disparate set of evidence, from Caesar and Tacitus to Anglo-Saxon lore and Icelandic sagas, spanning almost 1500 years and ranging from Italy to Scandinavia. Recent research has picked much of this grandiose "Germanic" edifice apart. ${ }^{108}$

The material discussed above suggests that oral genealogical memory can be made plausible in some cases, but the evidence is too patchy to generalize. Furthermore, several observations do not seem to fit the picture of a coherent Germanic interest in genealogies ignored in much of the written record. Genealogical thinking and pride in ancient ancestry had in fact been strong in classical Roman culture, and it was also important in the Old Testament. Why should Christian Latin authors have suppressed it? The experimental beginnings of Carolingian genealogies strongly suggest that there was no ancient family tradition that could simply be put into writing. Furthermore, no distinctive "Germanic" genealogical practice emerges. The gth-century Historia Brittonum takes a rather similar approach to the coeval Anglo-Saxon Chronicle and also includes numerous genealogies. ${ }^{109}$ Indeed, as David Dumville has demonstrated, Anglo-Saxon genealogies show certain British features, and Irish missionaries may have had an impact on them. ${ }^{110}$ In Ireland there is an abundance of genealogies. In a way reminiscent of the tribes of Yemen, kindreds were named after a putative common ancestor, for instance, the Uí Néill, the descendants of Níall, a dynasty that dominated in the north of Ireland

106 Scheibelreiter, "Genealogie".

107 Beck, "Genealogie".

108 Beck, ed., Germanenprobleme in heutiger Sicht; Pohl, Germanen; Geary, Myth of Nations.

109 Historia Brittonum, 7-10, ed. Mommsen, pp. 149-52, tracing the Britons back to Aeneas and his grandson Brutus/Britto, and various genealogies added later; see also Bartrum, Early Welsh Genealogical Tracts.

110 Dumville, "Kingship, Genealogies and Regnal Lists", 80-83; cf. Ireland, "Aldfrith of Northumbria". 
since the 6th century. ${ }^{111}$ Even Irish saints could be placed in these lineages. A manuscript from St Gall from the first half of the 9th century contains brief genealogies of its Irish founder saint, Gallus, and of St Bridget, both supposedly from royal Irish stock. ${ }^{112}$ The insular manuscript compendia, in which the great Irish genealogies are transmitted, are relatively late (mostly uth century), but the age in which these genealogies mattered seems to have been before c. 80o, whereas interest in them later declined. ${ }^{113}$ Irish scholars have often assumed that this was authentic Irish oral material faithfully written down by monks. Donnchadh O'Corrain, however, has argued that oral lore, as far as traces have been preserved, and written genealogies were organized quite differently, and that the model for the latter was the Old Testament. ${ }^{114}$

As mentioned above, genealogical thinking could indeed find numerous models in the Bible. These common biblical-ethnic origins were both familiar and generally accepted, and situated in a very distant past. In the 9th century, as we have seen, the genealogies of Anglo-Saxon kings were the first to be connected to the sons of Noah. Occasionally, dynastic pedigrees could be more or less explicitly linked to the origins of a people, as in the prologue of Aethelweard's late-1oth-century Latin translation of the Anglo-Saxon Chronicle: he would relate "what is known about our common family (prosapia) and also about the migration of our stock (genus)".115 And the 12th-century Textus Roffensis introduces its copy of the Anglian royal genealogy as Angel Cynnes Cyne Cynn, "the kingly kin of the Anglian people". ${ }^{16}$ In their structure, however, genealogies of peoples, gentes, were largely dissociated from family pedigrees. Belonging to Goths, Franks or Angles/Saxons conveyed privilege in the respective kingdoms, like belonging to the Qurashīs did in the Umayyad Caliphate. But there was little need to prove this privileged status by extending family pedigrees unequivocally to tribal ancestors.

The same applies to another genealogy of peoples that was copied into several early medieval manuscripts in slightly differing versions, the so-called "Frankish Table of Nations", probably going back to the 6th century. ${ }^{117}$ It was

\footnotetext{
111 Charles-Edwards, Early Irish and Welsh Kinship; Charles-Edwards, Early Christian Ireland, 84-95.

112 Codex Sangallensis 553, p. 263, http://www.e-codices.unifr.ch/en/list/one/csg/o553, accessed 25/12/2014. Edited as Genealogia Sancti Galli, ed. Pertz, p. 34. Even the (Latin) names of St Patrick's parents were noted. See Löwe, "Irische Genealogien aus St. Gallen".

113 O'Corrain, "Irish Origin Legends and Genealogy".

114 O'Corrain, "Creating The Past"; Charles-Edwards, Early Irish and Welsh Kinship.

115 The Chronicle of Aethelweard, ed. Campbell, p.1; Anlezark, Water and Fire, 246.

116 Anlezark, Water and Fire, 250, after Textus Roffensis, ed. Hearne, pp. 59-6o.

117 Goffart, "Frankish Table”.
} 
obviously built on the three sons of the mythical Germanic ancestor Mannus, found in the "Germania" by Tacitus, from whom he says the Ingaevones, Istaevones and Hermiones were descended. ${ }^{118}$ The Table of Nations does not mention the Germans; Mannus appears in some versions in the corrupted form Alanus. Four (or five) peoples were attached to each ancestor-not only Germanic peoples: for instance, Romans, Britons, Franks and Alamanni were grouped together as descendants of Istio/Escio. ${ }^{119}$ No direct link with family pedigrees emerges; even in the Codex Sangallensis 732, where this text is inserted between a Roman and a Frankish dynastic king list (paradoxically, the Germanic ancestor Mannus has moved into the king list as the first Roman king Analeus). This strange overlap between an ethnic and a royal genealogy shows that no coherent argument could be derived from their combination, apart from referring to the common origin of Romans and Franks.

We can conclude from these observations that no simple model fits the manifold evidence. On the one hand, the genealogies transmitted to us were not just Latin-Christian fabrications, although they were often written down by educated clerics - therefore we should not exclude possible "native" elements in them from our analysis. On the other hand, they certainly do not add up to any coherent "Germanic (genealogical) culture" that would be common to the continent, and more visible in England and Scandinavia. Neither do genealogies simply represent archaic thinking and oral practices that gradually lose their authenticity and significance when incorporated in a written culture. Rather they offer ways of structuring the social world and its perception which may lose or gain importance in societies of very different complexity. Tracing pedigrees kept many humanist intellectuals of the Renaissance busy in the service of their princes, and it still motivates much professional and dilettante research today. The relative social significance of genealogical arguments in a society thus cannot simply be deduced from its archaic character; neither is it a direct expression of the forms of kinship prevalent in these societies and their importance. Kinship structures, inheritance patterns, gender roles, ethnic identifications and distinctions, eligibility for office, the legitimation of rulership or styles of social cognition may all have had an influence on the production and dissemination of genealogies. Indeed, as Jack Goody has shown, kinship patterns seem to have changed profoundly in the course of Late Antiquity and the Early Middle Ages in Latin-Christian Europe. ${ }^{120}$ Studying the uses of genealogies may help to historicize concepts of kinship

118 Tacitus, Germania 2; Pohl, Germanen, 56.

119 Tacitus, Germania 2.2; Goffart, "Frankish Table".

120 Goody, The Development. 
and ethnicity in the period. A thorough contextualization of the role of genealogies in the period would require further research; and it could profit from the rich and controversial debates about kinship in anthropology. ${ }^{121}$ The final section of this article can only indicate the direction in which recent research on early medieval kinship has moved, and what it can tell us about the social significance of genealogies.

\section{Kinship, Ethnicity and Genealogy}

It is obvious that Christianization and the end of the Roman ancestor cult marked a relevant change in ideas about kinship. In Roman religion, the memory of the ancestors was the task of the pater familias, and a place in the house was usually devoted to them. Christianity transformed this practice, and transgenerational remembrance came to be entrusted to specialists in Christian institutions. Soon donations for one's soul and for perennial remembrance became routine practices. To an extent this implied a decreasing sense of responsibility for the memoria in the family. ${ }^{122}$ In parallel, in Late Antiquity the classical Roman naming system of the tria nomina faded out. ${ }^{123}$ The Roman nomen gentilicium had expressed affiliation to a named patrilineal descent group called the gens (Claudia, Iulia, Flavia etc.). In spite of their often elaborate genealogies, these gentes were rather inclusive groups. Liberated slaves and new citizens could adopt a gentile name, often that of the emperor, so that in the later empire it gradually lost its distinctive character. Personal names thus balanced personal identification on the one hand, and subsumption under a rather inclusive group on the other. In the course of the "transformation of the Roman world", recognition of group or family affiliation was abandoned in favour of single names, whether they were Roman, Christian or Germanic. It is characteristic how Flavius, once denoting origin from the gens Flavia, was vastly extended as a nomen adopted by many new citizens after citizenship had been extended to all free inhabitants of the empire in 212; finally, it became a fossilized part of the Gothic and Lombard royal titles, flavius $N$. rex, as a marker of Roman institutional tradition. ${ }^{124}$ In the Germanic naming system characterized by its composite names, repetition of names in the next

121 See, for instance, Goody, "Kinship"; Goody, The Development; Parkin and Stone, eds., Kinship and Family; Godelier, The Metamorphoses of Kinship; Gingrich, "The Prophet's Smile".

122 Paxton, Christianizing Death.

123 Salway, "What's in a Name?"; Solin, "Entwicklung des römischen Namensystems"; Heinzelmann, "Les changements"; cf. Patzold and Ubl, eds., Verwandtschaft.

124 Wolfram, Intitulatio, $5^{6-76}$. 
generation (Nachbenennung), variation (e.g., the 6th-century Merovingian kings Theuderich-Theudebert-Theudebald) or alliteration showed continuing attention to filiation, but could only be understood by a much smaller circle. ${ }^{125}$ Family names only appeared in the late Middle Ages and laid the basis for the modern naming system.

It had long been recognized that the kinship system in the early medieval West was not agnatic and patrilineal. In the 196os, Karl Schmid and Georges Duby established a two-phase model of medieval European kinship: cognatic kinship prevailed until c. AD 1000, when the "feudal transformation" led to a more agnatic system and a flowering of patrilineal aristocratic lineages. ${ }^{126}$ This model is still found in handbooks but has largely been superseded; the terminology and practice of kinship also included cognatic kin after the 11th century. ${ }^{127}$ The two-stage model was also challenged by Jack Goody, who argued that Christianization implied fundamental changes in generational rites of passage, such as birth, marriage, and death, which not only came to be accompanied by Christian liturgy, but also structured by new taboos. In the course of these transformations the ancient Mediterranean clan system, shared with modifications by Israel, Greece and Rome, disappeared. ${ }^{128}$ The emerging Christian norms banned all practices by which wealthy families could seek to ensure a smooth passage of property from one generation to the next in the absence of direct male heirs. Legal ways to guard against biological contingencies in succession and inheritance, such as adoption, divorce, concubines or polygyny, were removed. ${ }^{129}$ Female rights of inheritance were protected, even where that did not match provisions in "Germanic" law codes, so that widows stood a fair chance of accessing the property of their husbands (which they then might donate to Christian institutions). Endogamy was increasingly outlawed. In the course of the $9^{\text {th }}$ century the Church pushed through sharp rules against incest up to the seventh grade, while occasional

125 Haubrichs, "Typen der anthroponymischen Indikation", 36-47.

126 Schmid, "Zur Problematik von Familie", 1-62; Duby, Le chevalier; cf. Bouchard, "The Carolingian Creation". I am grateful to Bernhard Jussen for an inspiring conversation about this and the following. See also Kellner, Ursprung, 71-77; Sabean and Teuscher, "Kinship in Europe".

127 Goetz, "Verwandtschaft um 100o"; Bouchard, Those of My Blood.

128 Goody, The Development, 222-39; see also Mitterauer, "European Kinship Systems”; id., "Mittelalter", 171-372; LeJan, Famille et pouvoir; Jussen, "Perspektiven", including a discussion of all types of exceptions to these rules.

129 Goody, The Development, 48-82; Jussen, "Perspektiven". 
attempts to ban foreign marriages came to nothing. ${ }^{130}$ These rules were not always respected, but they required a certain genealogical knowledge not only in the families but also by those who aspired to control them. Tables explaining the degrees of parenthood such as the one in Isidore of Seville's Etymologies were widely distributed, and offered early models of trees of consanguinity. ${ }^{131}$ Genealogical reasoning became a matter of canon law. Christianity thus did not simply sever genealogical thinking in favour of a purely Christian identity, but rather contributed to reconfiguring it. In a sense, it even insisted much more firmly than the Roman kinship system on its God-given biological character, with a measure of cognatic awareness in attitudes towards kinship. Goody sought to explain these changes as a policy of Christian leaders to ease bequests to the Church, in particular by rich widows, whose re-marriage was restricted. His diagnosis was influential among European medieval historians, although his explanations were not always judged satisfactory. The debate is still open, and it is not the aim of this contribution to engage in it. ${ }^{132}$

Recent research makes it clear that things were complex. Medieval kinship served many purposes: creating networks of mutual support, securing inheritance, legitimizing access to power and office, establishing legal responsibilities, negotiating status, defining gender roles, framing marriage alliances, providing maintenance for widows and orphans, and more. ${ }^{133}$ Patrilineal genealogies might serve some of these purposes but not others. For instance, proof of noble lineage as a prerequisite for public office or privilege seems to have developed relatively late in the Middle Ages. As recent research about late medieval and early modern genealogies has shown, aristocrats proud of their ancestry were not necessarily in contrast with an intensification of central rule and state administration. ${ }^{134}$

In any case, elaborate proof of noble ancestry was not necessary for a career at court in the Merovingian period; aristocratic competition in the post-Roman centuries does not seem to have relied on fancy pedigrees. We may see Merovingian or Carolingian succession as dynastic, but neither the name of the dynasty nor the exact line of descent was highlighted in the sources; what mattered was the order of succession of kings, which was filial by default and

\footnotetext{
130 Ubl, Inzestverbot; id., "Bischöfe"; de Jong, "An Unsolved Riddle"; Pohl, "Why not Marry a Foreign Woman?"

131 Isidor, Etymologiae, 9.6, ed. Lindsay; cf. Kellner, Ursprung, 34-43.

132 Jussen, "Erbe"; Ubl, Inzestverbot; Sabean and Teuscher, "Kinship in Europe".

133 Spieß, Familie.

134 Sabean and Teuscher, "Kinship in Europe".
} 
might include other forms of kinship, but rarely required more sophisticated genealogical arguments. In the Latin West from the 6th to the 8th century, therefore, genealogies were not the prevalent form in which political legitimacy, social status and inheritance rights were negotiated, or in which memories of the past were structured. Those that have been transmitted represent a broad spectrum of forms. Royal dynasties could have long or short genealogies. These could include material from classical mythology, Scandinavian or Germanic traditions, or biblical genealogies; they highlighted royal ancestry or not; they might feature eponymous heroes, pagan gods, Old-Testament figures or Roman senators; they were presented in descending or ascending lines, including (or more frequently excluding) women. There was no received model or widespread practice that the transmitted examples followed. One has the impression that self-assured and smoothly-tailored memories of ancient heritage needed time to unfold after the crisis of identity that the dissolution of empire had provoked, not only for the Romans but also for the composite "barbarian" groups that succeeded them in power. Succession in kingship might require genealogical legitimation, but often did not. When, for instance, Frankish kingship passed from the Merovingians to the Carolingians in 751, genealogical succession (that is, some form of descent of the new ruling family from the old one) was not used as an argument, while many other legitimations were sought. There is little evidence of genealogical reasoning in aristocratic competition for office or in disputes over inheritance.

The secondary role of genealogies in the early medieval West, however, does not mean that kinship as a whole had become unimportant. ${ }^{135}$ In many contexts, ego-related perspectives of parenthood were more important that ancestor-related ones. ${ }^{136}$ Knowing who one's kin was could be essential in many respects, not least in legal matters. In Lombard law, a number of oathhelpers from the kin-group could clear someone of a suspicion. That implies, of course, a certain genealogical knowledge. For all practical purposes, a memory of three or four generations and their offspring would suffice-a genealogical horizon represented by many of the examples cited above. A similarly limited perspective applied to ethnic identifications. Early medieval peoples had emerged from quite heterogeneous elements in the course of the "migration period" between the 4th and 6th centuries. We do not know how many Franks, Goths or Lombards in the post-Roman kingdoms claimed to be descended from a distant forefather from the same ethnic group, and how many actually were. But we have no indications that a long record of

135 Lubich, Verwandtsein; Ubl, "Zur Einführung".

136 For this distinction, see Goody, The Development, 134-42. 
identification with the same people was decisive for group affiliation or status in these kingdoms. For all that we know, the ethnic landscape of early medieval Europe was not perceived as immutable and unchanged since time immemorial. To ensure the success of their minority governments, Franks, Goths or Lombards did not emphasize the idea of common blood, either within one gens or between them. Ethnicity could only serve as a political expedient if integration was not prevented by insurmountable boundaries of blood and origin. Identification with the gens rather than with a more specific descent group could suffice for access to privilege. ${ }^{137}$ The Frankish myth of Trojan origin, which made the Franks relatives of the Romans, certainly helped to create a sense of common purpose between Frankish and Roman elites in the Frankish kingdoms. ${ }^{138}$ And indeed, in the long run, Frankish identity came to include the majority of the Romance-speaking "French". A similar merging of identities happened in Burgundy and Lombardy. There was no sense of any common "Germanic" identity that would have prevented such integration. It is remarkable that as early as in the course of the 4th century, the use of the umbrella term "Germani" for the Germanic-speaking peoples east of the Rhine and north of the Danube disappeared. ${ }^{139}$

The idea that the Franks were related to Trojans, Romans, Phrygians, Frisians and Turks, or the highly composite genealogy of the kings of Wessex, represent concepts of kinship between peoples very different from our modern views. In spite of all their differences of form and content, the genealogies of the early medieval West display a remarkably wide horizon. They included classical mythology, Old-Testament lineages, Christian saints, Germanic gods and Scandinavian heroes, and could criss-cross apparent ethnic divides. They do not come from a dark age in which barbarian rulers had fallen back on the narrow focus of their ethnic lore. To the contrary, they reflect a process of intellectual accommodation in an entangled ethnic landscape that was solidly set in a much wider world, and where the new elites sought to come to terms with a rich and manifold heritage. Faced with such a composite past, distinction could not simply be achieved by exclusion. Geat and Wodan, Noah and Adam could all be included in a single pedigree, and Geat might even be identified with a figure from Roman comedy.

Modern scholars used to regard such hybrid genealogies as erudite but insignificant speculations, and tried to extract "authentic" pedigrees from

\footnotetext{
137 Le Jan, Famille et pouvoir, 40: “Invoquer l'origine ethnique plutôt que des ancêtres"; Pohl, "Introduction: Strategies of Identification".

138 Reimitz, Frankish Identity and European Ethnicity, 83-87.

139 Pohl, "Germanenbegriff".
} 
them. However, the idea that only what seems coherent (for instance, purely Germanic) to us can be authentic is a modern projection that has led generations of excellent scholars astray. We may assume that core pedigrees were remembered in noble families. Later sagas and epics also contain many instances in which they were used for self-identification within an aristocratic milieu, were employed to express group affiliation, and could explain inherited bonds of friendship or enmity. These instances are rare in the early medieval record. Of course, royal (and aristocratic) succession was largely claimed by family members, even in those kingdoms where no stable dynasties emerged. However, it is notable that the generational transmission of office and lands was rarely accompanied by strong genealogical arguments (for instance, in contested cases), or by attempts to ascertain who belonged to a dynasty and who did not. There was no dynastic propaganda (with the exception of the Amals), and a family name was hardly used for identification. We do not even know whether the early Carolingians thought of themselves as Carolingians, as Arnulfings or as Pippinids. Information about royal succession was preserved in king lists which, however, rarely contain any genealogical information. It has become common to call the principle of filial succession "genealogical"; however, that is not very helpful for a distinction between various modes of representing kinship in past societies. Andre Gingrich, in his conclusion to the present volume, argues for a much more differentiated approach, which includes distinguishing between genealogy and descent, and addressing the particular circumstances of authorial decisions to streamline a genealogy into a unilinear descent order. As he maintains, "genealogical memories and descent reckoning are merely one of several strategic elements in any kinship system".

Those genealogies that we have served various purposes: royal legitimation (or perhaps, implicit critique, as in the Merovingian case), praise of a particular prince (often one who had died early), legal affirmation, securing inheritance rights (which in Bavaria only required the wholesale reference to "genealogia"), integrating different strands of a family or population, enhancing the prestige of a church or monastery, or displaying biblical and classical erudition. The art of genealogy in the period must have required balancing identities: barbarian and Roman, Christian and pagan, lay and clerical, distinctive and inclusive. It was a demanding task. Could genealogies, as Ibn Khaldun would say, lead to mutual help and affection? Straightforward lists of ancestors which did not provide points of reference for other groups in those hybrid societies, like Rothari's pedigree, do not seem to have become very popular. Distinction can rarely be achieved simply by being different. More open constructions, such as the Frankish Trojan legend or the Anglo-Saxon genealogies, achieved much wider currency. They made it possible to place common origins 
in a distant but familiar past, increasingly provided by biblical models. We may assume that it took time to develop genealogical schemes that could achieve the balance required to place a lineage within a complex web of kinship, ethnicity and shared Christian history. Only then could genealogy again become a widely-understood idiom of distinction within a common frame of identification.

\section{Bibliography}

Daniel Anlezark, Water and Fire: The Myth of the Flood in Anglo-Saxon England (Manchester, New York, 2006).

Aleida Assmann, Zeit und Tradition: Kulturelle Strategien der Dauer (Cologne, 1999).

Peter Bartrum, Early Welsh Genealogical Tracts (Cardiff, 1966).

Heinrich Beck, ed., Germanenprobleme in heutiger Sicht, Ergänzungsbände zum Reallexikon der germanischen Altertumskunde 1 (Berlin, 1986).

Heinrich Beck, "Genealogie", in Reallexikon der germanischen Altertumskunde n, ed. Heinrich Beck, 2nd rev. ed. (Berlin, 1998), 54-55.

Teresa Bernheimer, The 'Alids: The First Family of Islam, 750-1200 (Edinburgh, 2014).

Arno Borst, Der Turmbau von Babel: Geschichte der Meinungen über Ursprung und Vielfalt der Sprachen und Völker, 1 (Stuttgart, 1957).

Constance Bouchard, "The Carolingian Creation of a Model of Patrilineage", in Paradigms and Methods in Early Medieval Studies, eds. Felice Lifshitz and Celia Chazelle (New York, 2007), 194-220.

Constance Bouchard, Those of My Blood: Constructing Noble Families in Medieval Francia (Philadelphia, 2001).

Thomas Charles-Edwards, Early Irish and Welsh Kinship (Oxford, 1993).

Thomas Charles-Edwards, "Anglo-Saxon Kinship Revisited", in The Anglo-Saxons from the Migration Period to the Eighth Century: An Ethnographic Perspective, ed. John Hines (Woodbridge, 1997), 171-203.

Thomas Charles-Edwards, Early Christian Ireland (Cambridge, 2000).

Richard Corradini, "ZeitNetzWerk: Karolingische Gelehrsamkeit und Zeitforschung im Kompendium des Walahfrid Strabo"(unpublished Habilitationsschrift, University of Vienna, 2014).

Gilbert Dagron, Emperor and Priest: The Imperial Office in Byzantium (Cambridge, 2003).

Georges Duby, "The eleventh and twelfth centuries", in id., The Chivalrous Society, trans. Cynthia Postan (London, 1977), 149-57.

Georges Duby, Le chevalier, la femme et le prêtre: Le mariage dans la France féodale (Paris, 1981). 
David N. Dumville, "The Anglian Collection of Genealogies and Regnal Lists", AngloSaxon England 5 (1976), 23-50.

David N. Dumville, "Kingship, Genealogies and Regnal Lists", in Early Medieval Kingship, eds. Peter Hayes Sawyer and Ian N. Wood (Leeds, 1977), 72-104.

David N. Dumville, "The West Saxon Genealogical Regnal List and the Chronology of Early Wessex", Peritia 4 (1985), 21-66.

Karl August Eckhardt, "Exkurs IV: Merowinger im Dyptichon Barberini”, in Karl August Eckhardt, Studia Merovingica (Aalen, 1975).

Guy Farney, Ethnic Identity and Aristocratic Competition in Republican Rome (Cambridge, 2007).

Paul Fouracre and Richard Gerberding, Late Merovingian France: History and Hagiography, 640-720 (Manchester, 1996).

Patrick J. Geary, Phantoms of Remembrance: Memory and Oblivion at the End of the First Millennium (Princeton, 1994).

PatrickJ. Geary, The Myth of Nations: the MedievalOrigins of Europe (Princeton, NJ, 2002). Léopold Génicot, Les généalogies (Turnhout, 1975).

Andre Gingrich, “The Prophet's Smile and Other Puzzles: Studying Arab Tribes and Comparing Close Marriages", Social Anthropology 3,2 (1995), 147-70.

Maurice Godelier, The Metamorphoses of Kinship (New York, 2011).

Hans-Werner Goetz, "Verwandtschaft um 1000: ein solidarisches Netzwerk?" in Verwandtschaft, Name und soziale Ordnung (300-100o), eds. Steffen Patzold and Karl Ubl (Berlin, Boston, 2014), 289-302.

Walter Goffart, "The Supposedly 'Frankish' Table of Nations: An Edition and Study", Frühmittelalterliche Studien 17 (1983), 98-130.

Walter Goffart, The Narrators of Barbarian History (A.D. 550-80o):Jordanes, Gregory of Tours, Bede, and Paul the Deacon (Princeton, NJ, 1988).

Anthony Good, "Kinship", in The Routledge Encyclopedia of Social and Cultural Anthropology, eds. Alan Barnard and Jonathan Spencer, 2nd ed. (London, 2012), 396-404.

Jack Goody, The Development of the Family and Marriage in Europe (Cambridge, 1983).

Jana Grusková and Gunther Martin, "Ein neues Textstück aus den 'Scythica Vindobonensia' zu den Ereignissen nach der Eroberung von Philippopolis", Tyche 29 (2014), 29-44.

Wolfgang Haubrichs, "Amalgamierung und Identität: Langobardische Personennamen in Mythos und Herrschaft", in Die Langobarden-Herrschaft und Identität, eds. Walter Pohl and Peter Erhart, Forschungen zur Geschichte des Mittelalters 8 (Vienna, 2005), 67-102.

Wolfgang Haubrichs, “Typen der anthroponymischen Indikation von Verwandtschaft bei den 'germanischen' gentes: Traditionen-Innovationen-Differenzen", in 
Verwandtschaft, Name und soziale Ordnung (300-100o), eds. Steffen Patzold and Karl Ubl (Berlin, Boston, 2014), 29-71.

Peter Heather, The Goths in the Fourth Century (Liverpool, 1991).

Peter Heather, Goths and Romans 332-489 (Oxford, 1991).

Martin Heinzelmann, "Les changements de la dénomination latine à la fin de l'antiquité", in Famille et parenté dans l'occident médiéval, eds. Georges Duby and Jacques LeGoff (Rome, 1977), 19-24.

Martin Heinzelmann, "L'hagiographie mérovingienne: Panorama des documents potentiels", in Monique Goullet, Martin Heinzelmann and Christiane VeyrardCosme, L'hagiographie mérovingienne à travers ses réécritures (Beihefte der Francia 71, Ostfildern, 2010), 27-82.

Olivier Hekster, Emperors and Ancestors: Roman Rulers and the Constraints of Tradition (Oxford, 2015).

Colin A. Ireland, "Aldfrith of Northumbria and the Irish Genealogies", Celtica 22 (1991), $64-78$.

Mayke de Jong, "An Unsolved Riddle: Early Medieval Incest Legislation”, in Franks and Alamanni in the Merovingian Period: An Ethnographic Perspective, ed. Ian Wood (San Marino, 1998), 107-40.

Bernhard Jussen, "Perspektiven der Verwandtschaftsforschung zwanzig Jahre nach Jack Goody's 'Entwicklung von Ehe und Familie in Europa', in Die Familie in der Gesellschaft des Mittelalters, ed. Karl-Heinz Spieß (Ostfildern, 2009), 275-324.

Bernhard Jussen, "Erbe und Verwandtschaft: Kulturen der Übertragung im Mittelalter", in Erbe: Übertragungskonzepte zwischen Natur und Kultur, eds. Stefan Willer, Sigrid Weigel and Bernhard Jussen (Frankfurt/M., 2013), 37-64.

Beate Kellner, Ursprung und Kontinuität: Studien zum genealogischen Wissen im Mittelalter (Munich, 2004).

Damien Kempf, “Introduction”, in Paulus Diaconus, Liber de Episcopis Mettensibus, ed. and trans. Damien Kempf, Dallas Medieval Texts and Translations 19 (Paris, Leuven, Walpole MA, 2013), 1-39.

Hugh Kennedy, "Arab Genealogical Literature from Oral Memory to Written Record", Arabica 44 (1997), 531-44.

Bojana T. Ksrmanović and Ninoslava J. Radošević, "Legendary genealogies of Byzantine emperors and their families", Zbornik Radova Vizantološkog Instituta 41 (2004), $71-98$.

Régine LeJan, Famille et pouvoir dans le monde franc (VIIe-Xe siécle): Essai d'anthropologie sociale (Paris, 1995).

Conrad Leyser, "From Maternal Kin to Jesus as Mother: Royal Genealogy and Marian Devotion in the Ninth-Century West", in Motherhood, Religion and Society in Medieval Europe, 400-140o: Essays Presented to Henrietta Leyser, eds. Conrad Leyser and Lesley Smith (Farnham, 2011), 21-40. 
Heinz Löwe, "Irische Genealogien aus St. Gallen und ihr historischer Hintergrund", in Tradition als historische Kraft, eds. Norbert Kamp and Joachim Wollasch (Berlin, 1982), 138-55.

Gerhard Lubich, Verwandtsein: Lesarten einer politisch-sozialen Beziehung im Frühmittelalter (6.-11.Jh.) (Cologne, 2008).

Gunther Martin and Jana Grusková, “Scythica Vindobonensia' by Dexippus (?): New Fragments on Decius' Gothic Wars", Greek, Roman and Byzantine Studies 54 (2014) 728-54; online: http://grbs.library.duke.edu/article/view/15071/6581.

Rosamond McKitterick, Charlemagne: The Formation of a European Identity (Cambridge, 2008).

Michael Mitterauer, "European Kinship Systems and Household Structures: Medieval Origins", in Distinct Inheritances: Property, Family and Community in a Changing Europe, eds. Hannes Grandits and Patrick Heady (Münster, 2003), 35-52.

Michael Mitterauer, "Mittelalter", in Andreas Gestrich, Jens-Uwe Krause and Michael Mitterauer, Geschichte der Familie: mit 17 Tabellen (Stuttgart, 2003), 171-372.

Alexander Callander Murray, "Beowulf, the Danish Invasions, and Royal Genealogy", in The Dating of Beowulf, ed. Colin Chase (Toronto, 1981), 101-11.

Alexander Callander Murray, Germanic Kinship Structure: Studies in Law and Society in Antiquity and the Early Middle Ages (Toronto, 1983).

Janet L. Nelson, "Reconstructing a Royal Family: Reflections of Alfred, from Asser, Chapter 2", in Peoples and Places in Northern Europe, 500-16oo: Essays in Honour of Peter Hayes Sawyer, eds. Ian Wood and Niels Lund (Woodbridge, 1991), 47-66.

Janet L. Nelson, "Charlemagne the Man", in Charlemagne: Empire and Society, ed. Jo Story (Manchester, 2005), 22-37.

Donnchadh O'Corrain, "Irish Origin Legends and Genealogy: Recurrent Aetiologies", in History and Heroic Tale, ed. Tore Nyberg (Odense, 1985), 51-96.

Donnchadh O'Corrain, "Creating the Past: The Early Irish Genealogical Tradition: The Carroll Lecture 1992", Chronicon 1,2 (1997) 1-32.

Otto Gerhard Oexle, "Die Karolinger und die Stadt des heiligen Arnulf", Frühmittelalterliche Studien 1 (1967), 250-364.

James T. Palmer, Anglo-Saxons in a Frankish World 69o-9oo (Turnhout, 2009).

Robert Parkin and Linda Stone, eds., Kinship and Family: An Anthropological Reader (Oxford, Malden, 2004).

Steffen Patzold and Karl Ubl, eds., Verwandtschaft, Name und soziale Ordnung (300100o), Ergänzungsbände zum Reallexikon der germanischen Altertumskunde 90 (Berlin, 2014).

Frederick S. Paxton, Christianizing Death: the Creation of a Ritual Process in Early Medieval Europe (Ithaca, NY, 1990).

Walter Pohl, Die Germanen, 2nd ed., Oldenbourgs Enzyklopädie der deutschen Geschichte 57 (Munich, 2002). 
Walter Pohl, "Der Germanenbegriff vom 3. bis 8. Jahrhundert-Identifikationen und Abgrenzungen”, in Zur Geschichte der Gleichung 'germanisch-deutsch', eds. Heinrich Beck, Dieter Geuenich, Heiko Steuer and Dietrich Hakelberg, Ergänzungsbände zum Reallexikon der germanischen Altertumskunde 34 (Berlin, New York, 2004), 163-83.

Walter Pohl, "Gender and Ethnicity in the Early Middle Ages", in Gender in the Early Medieval World: East and West, 300-9oo, eds. Leslie Brubaker and Julia Smith (Cambridge, 2004), 23-43 or in From Roman Provinces to Medieval Kingdoms, ed. Thomas F.X. Noble (London, 2006), 168-88.

Walter Pohl, "Gens ipsa peribit: Kingdom and Identity after the End of Lombard Rule", in 774-ipotesi su una transizione, ed. Stefano Gasparri (Turnhout, 2008), 67-78.

Walter Pohl, "Introduction: Ethnicity, Religion and Empire", in Visions of Community in the Post-Roman World: The West, Byzantium and the Islamic World, 300-110o, eds. Walter Pohl, Clemens Gantner and Richard Payne (Farnham, Burlington, 2012), 1-23. Walter Pohl, "Introduction: Strategies of Identification: A Methodological Profile", in Strategies of Identification: Ethnicity and Religion in Early Medieval Europe, eds. Walter Pohl and Gerda Heydemann, Cultural Encounters in Late Antiquity and the Middle Ages 13 (Turnhout, 2013), 1-64.

Walter Pohl, "Why not Marry a Foreign Woman: Stephen III's Letter to Charlemagne", in Rome and Religion in the Early Middle Ages, eds. Valerie Garver and Owen Phelan (Farnham, 2014), 47-63.

Walter Pohl, “Morbus Gothorum':Nachfolgeproblemebei Westgoten undLangobarden”, in The Arts of Succession, eds. Ulrich Gotter and Nino Luraghi, forthcoming.

Helmut Reimitz, "Ein karolingisches Geschichtsbuch aus St Amand", in Text-SchiftCodex: Quellenkundliche Arbeiten aus dem Institut für Österreichische Geschichtsforschung, eds. Herwig Weigl and Christoph Egger, Mitteilungen des Instituts für Österreichische Geschichtsforschung, Ergänzungsband 35 (Vienna, 2000), 34-90.

Helmut Reimitz, "Anleitung zur Interpretation: Schrift und Genealogie der Karolingerzeit", in Vom Nutzen des Schreibens: Soziales Gedächtnis, Herrschaft und Besitz, eds. Walter Pohl and Paul Herold, Forschungen zur Geschichte des Mittelalters 5 (Vienna, 2002), 167-82.

Helmut Reimitz, "Die Konkurrenz der Ursprünge in der fränkischen Historiographie”, in Die Suche nach den Ursprüngen: Von der Bedeutung des frühen Mittelalters, ed. Walter Pohl, Forschungen zur Geschichte des Mittelalters 8 (Vienna, 2004), 191-210. Helmut Reimitz, History, Frankish Identity and the Framing of European Ethnicity, 550$85^{\circ}$ (Cambridge, 2015).

Majied Robinson, "Prosopographical Approaches to the Nasab Tradition: A Study of Marriage and Concubinage in the Tribe of Muhammad, 500-750 CE" (PhD thesis, University of Edinburgh, 2013). 
David Sabean and Simon Teuscher, "Kinship in Europe: A new approach to long-term development", in Kinship in Europe: Approaches to long-term development (1300190o), eds. David Warren Sabean, Simon Teuscher and Jon Mathieu (Oxford, 2007), $1-32$.

Benet Salway, "What's in a Name? A Survey of Roman Onomastic Practice from c. 700 BC to 700 AD", Journal of Roman Studies 84 (1994), 124-45.

Sarah Bowen Savant and Helena de Felipe, eds., Genealogy and Knowledge in Muslim Societies: Understanding the Past (Edinburgh, 2014).

Georg Scheibelreiter, "Genealogie", in Reallexikon der germanischen Altertumskunde 11, ed. Heinrich Beck, 2nd rev. ed. (Berlin, 1998), 33-45.

Karl Schmid, "Zur Problematik von Familie, Sippe und Geschlecht, Haus und Dynastie beim mittelalterlichen Adel", Zeitschrift für Geschichte des Oberrheins 105 (1957), $1-62$.

Clausdieter Schott, Lex Alamannorum. Codex Sangallensis 731: Faksimile, Text, Übersetzung, Kommentar zum Faksimile aus der Wandalgarius-Handschrift, 2nd ed. (Augsburg, 1993).

Rudolf Simek, Lexikon der germanischen Mythologie (Stuttgart, 2006).

Heikki Solin, "Zur Entwicklung des römischen Namensystems", in Person und Name, eds. Dieter Geuenich, Wolfgang Haubrichs and Jörg Jarnut (Berlin, New York, 2003), 1-17.

Gabrielle Spiegel, "Genealogy: Form and Function in Medieval Historiography", in id., The Past as Text: The Theory and Practice of Historiography (Baltimore, London, 1997), 99-110.

Karl-Heinz Spieß, Familie und Verwandtschaft im deutschen Hochadel des Spätmittelalters: 13. bis Anfang des 16. Jahrhunderts (Stuttgart, 1996).

Zoltán Szombathy, The Roots of Arabic Genealogy: A Study in Historical Anthropology (Berlin, 2003).

Marcelle Thiébaux, "Introduction", in Dhuoda, Liber Manualis, ed. Marcelle Thiébaux, Cambridge Medieval Classics (Cambridge, 1998), 1-39.

David E. Thornton, "Genealogies, Royal", in The Blackwell Encyclopedia of Anglo-Saxon England, ed. Michael Lapidge (Oxford, 1999), 199-200.

Karl Ubl, Inzestverbot und Gesetzgebung: Die Konstruktion eines Verbrechens, 300-1100 (Berlin, 2008).

Karl Ubl, "Bischöfe und Laien auf dem Konzil von Tribur 895: Zur Politisierung der Ehe in der Karolingerzeit”, Deutsches Archiv 70,1 (2014), 143-62.

Karl Ubl, "Zur Einführung: Verwandtschaft als Ressource sozialer Integration im frühen Mittelalter", in Verwandtschaft, Name und soziale Ordnung (300-100o), eds. Steffen Patzold and Karl Ubl (Berlin, Boston, 2014), 1-28.

Jean Vezin, "Une nouvelle lecture de la liste de noms copiée au dos de l'ivoire Barberini”, Bulletin archéologique, Nouvelle Serie 7 (1971), 19-53. 
Jeffrey Weaver and Madeline H. Caviness, The Ancestors of Christ Windows at Canterbury Cathedral (Los Angeles, 2013).

Reinhard Wenskus, Stammesbildung und Verfassung: Das Werden der frühmittelalterlichen gentes, 2nd ed. (Cologne, Vienna, 1977).

Charles West, "Dynastic Historical Writing", in The Oxford History of Historical Writing, 2: 40o-140o, eds. Sarah Foot and Chase F. Robinson (Oxford, 2012), 496-516.

Armin Wolf, "Königswähler und königliche Tochterstämme”, in Königliche Tochterstämme, Königswähler und Kurfürsten, ed. Armin Wolf (Frankfurt/M., 2002), 1-78.

Herwig Wolfram, Intitulatio: 1 Lateinische Königs- und Fürstentitel bis zum Ende des 8. Jahrhunderts (Vienna, Cologne, Graz, 1967).

Herwig Wolfram, History of the Goths (Berkeley, 1988).

Herwig Wolfram, Gotische Studien: Volk und Herrschaft im frühen Mittelalter (Munich, 2005).

Ian N. Wood, "Fredegar's Fables", in Historiographie im frühen Mittelalter, eds. Anton Scharer and Georg Scheibelreiter, Veröffentlichungen des Instituts für Österreichische Geschichtsforschung 32 (Vienna, 1994a), 359-66.

Ian N. Wood, The Merovingian Kingdoms 450-751 (London, New York, 1994b).

Ian N. Wood, Gregory of Tours (Bangor, Oxford, 1994c).

Ian N. Wood, "The Individuality of Gregory of Tours", in The World of Gregory of Tours, eds. Kathleen Mitchell and Ian Wood (Leiden, Boston, 2002), 29-46.

Ian N. Wood, "Deconstructing the Merovingian Family", in The Construction of Communities in the Early Middle Ages: Texts, Resources and Artefacts, eds. Richard Corradini, Max Diesenberger and Helmut Reimitz, The Transformation of the Roman World 12 (Leiden, Boston, 2003), 149-72.

Ian N. Wood, "Genealogy Defined by Women: the Case of the Pippinids", in Gender in the Early Medieval World: East and West, 300-90o, eds. Leslie Brubaker and Julia Smith (Cambridge, 2004), 234-56.

\section{Sources}

The Anglo-Saxon Chronicles, trans. Michael Swanton (London, 2000).

Asser, Life of King Alfred, trans. Simon Keynes and Michael Lapidge (Harmondsworth, 1983).

Bede, Historia Ecclesiastica, ed. and trans. Bertram Colgrave and Roger A.B. Mynors (Oxford, repr. 1992).

Theodor Bitterauf, Die Traditionen des Hochstifts Freising 1: 744-926, Quellen und Erörterungen zur bayerischen und deutschen Geschichte N.F. 4 (Munich, 1905).

Bonifatius, Epistolae, ed. Michael Tangl, Monumenta Germaniae Historica (hereafter MGH) Epistolae selectae 1 (Berlin, 1916).

Cassiodorus, Variae, translated with notes and introduction by Sam J.B. Barnish, (Liverpool, 1992). 
Catalogi regum Francorum praetermissi, ed. Bruno Krusch, MGH Scriptores rerum Merovingicarum 7 (Hanover, Leipzig, 1920), pp. 850-55.

Chronica de VI aetatibus mundi = Die ostfränkische Ahnentafel von 807, ed. Arno Borst, MGH Quellen zur Geistesgeschichte des Mittelalters 21/2 (Hanover, 2006), pp. 951-1008.

The Chronicle of Aethelweard, ed. Alistair Campbell (London, 1962).

Commemoratio genealogiae domni Karoli gloriosissimi imperatoris, ed. Georg Waitz, MGH Scriptores 13 (Hanover, 1881), pp. 245-46.

The Burgundian Code: book of constitutions or law of Gundobad, trans. Katherine Fischer Drew (Philadelphia, 1996).

Collectio Pataviensis, ed. Karl Zeumer, Formulae Merov. et Carol. Aevi (Hanover, 1886), pp. 456-61.

Concilium Parisiense a. 829, ed. Albert Werminghoff, MGH Concilia Aevi Carolini 1, 2 (Hanover, 1908), p. 655.

Dhuoda, Liber Manualis, ed. Marcelle Thiébaux, Cambridge Medieval Classics (Cambridge, 1998).

Paulus Diaconus, Liber de Episcopis Mettensibus, ed. Georg Heinrich Pertz, MGH Scriptores 2 (Hanover, 1829), pp. 26o-68.

Paulus Diaconus, Historia Langobardorum, eds. Ludwig Bethmann and Georg Waitz, MGH Scriptores rerum Langobardicarum et Italicarum (Hanover, 1878), pp. 45-187.

Eusebius, Historia Ecclesiastica, ed. Kirsopp Lake, 2 vols., Loeb's Classical Series (Cambridge, Mass., 1926).

Venantius Fortunatus, Poèmes, vols. 1-3, ed. Marc Reydellet, Collection des universités de France, Série latine 315, 374, 376 (Paris, 1994-2004).

Fredegar, Chronicae, ed. Bruno Krusch, MGH Scriptores rerum Merovingicarum 2 (Hanover, 1888), pp. 18-193.

Genealogiae Karolorum, ed. Georg Waitz, MGH Scriptores 13 (Hanover, 1881), pp. 241-48.

Genealogia ex stirpe sancti Arnulfi descendentium Mettensis, ed. Johannes Heller, MGH Scriptores 25 (Hanover, 1880), pp. 381-85.

Genealogia Sancti Galli, ed. Georg Heinrich Pertz, MGH Scriptores 2 (Hanover, 1829), p. 34. Genealogia Welforum, ed. Georg Waitz, MGH Scriptores 13 (Hanover, 1881), pp. 733-34. Gregory of Tours, Historiae, eds. Bruno Krusch and Wilhelm Levison, MGH Scriptores rerum Merovingicarum 1/1 (Hanover, 1937).

Gregory of Tours, Life of the Fathers, trans. Edward James, Translated texts for historians: Latin series 1 (Liverpool, 1986).

Historia Brittonum, ed. Theodor Mommsen, MGH Auctores antiquissimi 13 (Berlin, 1898), pp. 111-222.

Isidore, Chronica Maiora, ed. Theodor Mommsen, MGH Auctores antiquissimi 11 (Berlin, 1894), pp. 424-79. 
Isidore, Etymologiae, ed. Wallace M. Lindsay, 2 vols. (Oxford, 1911; repr. 1991).

Jonas of Orléans, De institutione regia, ed. Alain Dubreucq, Sources Chrétiennes 407 (Paris, 1995).

Jordanes, Romana, ed. Theodor Mommsen, MGH Auctores antiquissimi 5/1 (Berlin, 1882), pp. 1-52.

Jordanes, Getica, ed. Theodor Mommsen, MGH Auctores antiquissimi 5/1 (Berlin, 1882), pp. 53-138.

Ibn Khaldun, Muqadimmah: an introduction to history, trans. Franz Rosenthal, ed. Nessim Joseph Dawood (Princeton, N.J., 2005).

Lex Baiwariorum, ed. Ernst von Schwind, MGH Leges nationum Germanicarum 5/2 (Hanover, 1926).

Liber Historiae Francorum, ed. Bruno Krusch, MGH Scriptores rerum Merovingicarum 2 (Hanover, 1888), pp. 215-328.

The Lombard Laws, trans. Katherine Fischer Drew (Philadelphia, 1973).

Origo gentis Langobardorum, eds. Ludwig Bethmann and Georg Waitz, MGH Scriptores rerum Langobardicarum et Italicarum (Hanover, 1878), pp. 2-6.

Regum Francorum Genealogiae, ed. Georg Heinrich Pertz, MGH Scriptores 2 (Hanover, 1829), pp. 307-14.

Textus Roffensis, ed. Thomas Hearne (Oxford, 1720).

Thegan, Vita Hludovici, ed. Ernst Tremp, MGH Scriptores rerum Germanicarum 64 (Hanover, 1995), pp. 167-278.

Vita Sanctae Geretrudis, ed. Bruno Krusch, MGH Scriptores rerum Merovingicarum2 (Hanover, 1888), pp. 447-64. 